\title{
Perception about Teaching and Learning Methodologies Applied in Physiology: A study on Medical Students of Pakistan
}

\author{
QUDSIA UMAIRA KHAN ${ }^{1}$, HAMEYL TAHIR ${ }^{2}$, ABDUR RAFAE AHMAD ${ }^{3}$ \\ ${ }^{1}$ Assistant Professor, Department of Physiology, CMH Lahore Medical College and Institute of Dentistry, Lahore. \\ ${ }^{2,3}$ Third Year MBBS Student. CMH Lahore Medical College and Institute of Dentistry, Lahore .hamyeltahir@hotmail.com \\ Correspondence to Dr Qudsia Umaira Khan, Email: drqudsia@yahoo.com Tel. 0300-4816979
}

\begin{abstract}
Background: The study of physiology is an essential part of the medical school curriculum. Medical teachers have identified the preference for a specific mode of content delivery to communicate knowledge to students in a rational, strategic, coherent, and sequential manner. In comparison to the focus on systems-based didactic lectures, more emphasis is now put on the developing critical thinking skills. Physiology is widely acknowledged as a difficult subject for medical students to grasp, incorporate, and apply in clinical sciences.

Aim: To learn about students' perceptions of teaching, learning, and assessment approaches used in the physiology.

Method A quantitative cross-sectional survey was conducted online on 533 medical students from first to final year and also post grate students. After the approval of Ethical review committee, a questionnaire to determine the various aspects of Physiology as a subject being taught. The survey was conducted online via "Google forms". Participants answered anonymously with informed consent, and the survey was conducted for a period of two months. Data was analyzed using SPSS version 23.

Results: A total number of 533 students participated in this research and responding to Physiology learning and teaching. When students were asked about that which subject is most interesting in first Year MBBS, majority of the students that is $46.2 \%$ of the responses claimed that Physiology is the most interesting subject. 33.6\% students were from 1st Year. 9.2\% students were Postgraduates. $63.4 \%$ of the students preferred studying physiology from Guyton and Hall as reference book for Physiology. Majority of students that is $25.5 \%$ of the students found Blood Physiology to be the most interesting. Whereas 19.8\% found Heart or Cardio Vascular System Physiology as the most interesting subject.15.6\% found cell and nerve muscle as an interesting topic in Physiology.9.6\% found Endocrinology and reproduction physiology as interesting as compared to $7.7 \%$ who found central Nervous system Physiology interesting. $43.9 \%$ of the students responded that they perfeer face to face interactive lectures.23.3\% of the students perfered small group discussion. $10.9 \%$ students prefered learing by tutorilas. Interestingly, $20.4 \%$ of the participants replied that they would definitely pursue physiology as their career.
\end{abstract}

Conclusion: Physiology is the most interesting subject preferred by majority of students.

Keywords: Perception, learning methodologies, medical students

\section{INTRODUCTION}

The study of physiology is an essential part of the medical school curriculum ${ }^{1}$. Medical teachers have identified the preference for a specific mode of content delivery to communicate knowledge to students in a rational, strategic, coherent, and sequential manner. In comparison to the focus on systems-based didactic lectures, more emphasis is now put on the developing critical thinking skills ${ }^{2}$. Physiology is widely acknowledged as a difficult subject for medical students to grasp, incorporate, and apply in clinical sciences. Furthermore, students may require the assistance of physiologists to understand core physiological concepts in the context of disease processes. As a result, medical educators are pondering how to achieve successful vertical and horizontal integration in the field of physiology ${ }^{3}$.

Regular evaluation of the medical teachers is needed over time to develop continually by fostering and implementing new teaching and learning approaches ${ }^{4}$. Physiology is taught using a variety of teaching and learning methods, including formal interactive sessions

Received on 28-03-2021

Accepted on 03-08-2021
(SIS), Interactive Lectures (IL), Problem-Based Learning (PBL), and Case-Based Lectures (CBL) $)^{5}$. It is important for Physiology faculty to become knowledgeable about the discipline, as well as different teaching and learning techniques and their effectiveness in achieving the objective of real student learning. The delivery of core conceptual understanding of physiological processes has progressed from didactic lectures to immersive IL. Teachers are better able to keep students interested and inspired in the classroom when lectures are well planned ${ }^{6}$.

First-year students of MBBS study physiology, anatomy, and biochemistry. Students are concentrating on quick ways to pass university exams by embracing short books, which is diluting the true standard of subject information ${ }^{7}$. For a medical professional employed in a medical institution, teaching is an inbuilt art that can be perfected by completing medical education training. The amount of learning must be assessed in the classroom, not the teaching style or process. The effectiveness of a lecture is determined by the lecturer's capacity ${ }^{8}$. Teaching, learning, and assessment are all essential components of an educational system that leads to a positive way of life. Unlike in the past, the first year of an MBBS course now lasts just one year, and students are always required to review the succinct notes of the three subjects in order to 
pass the university exams at the end of the first year. Due to a lack of intellectual comprehension, the educational standard suffers. The primary goal of medical education should be a holistic approach that improves medical professionals' problem-solving abilities through analytical and rational thought ${ }^{9}$.

In the last few years, tertiary education has undergone a major transformation. The focus has shifted from teaching facts to assisting students in learning how to locate relevant knowledge, evaluate it, and assemble disparate pieces of information into a coherent whole, and the physiological sciences are supporting this shift ${ }^{10}$. This resulted in a virtual explosion of new teaching and learning methods. Finding ways to evaluate them is becoming increasingly important ${ }^{11}$. As a result, educational research is needed, and continuous assessment must be considered a critical component of educational progress. Examination is the easiest way to assess outcome, and many researchers have tried educational assessment using examination. However, focusing on students' perceptions of their experience with a learning program is still the most pragmatic and practical approach in educational assessment, and this approach has been used in many studies $^{12}$.

We may adapt new teaching approaches to suit the students' learning styles and preferred learning modalities if we know what they are. The emphasis in the classroom should be on the quantity of learning rather than the quantity of the syllabus to be covered ${ }^{13}$. Until now, no research in Pakistan has evaluated whether current teaching, learning, and assessment methods are effective enough to impart information for effective learning.

The aim of this study is to learn about students' perceptions of teaching, learning, and assessment approaches used in the physiology department in terms of successful learning.

\section{MATERIALS AND METHODS}

Study Design: A quantitative cross-sectional survey will be conducted online on medical students from first to final year and also post grate students, studying with traditional or integrated curricular systems. A questionnaire to determine the various aspects of Physiology as a subject being taught, will be used to determine trends of students and across the years. Perception about Teaching and Learning Methodologies applied in Physiology, a study on Medical Students of Pakistan

The survey will be conducted online via "Google forms". Participants will answer anonymously with informed consent, and the survey was conducted for a period of three weeks. The study will be conducted in accordance with the declaration and approval of the Ethics Committee of $\mathrm{CMH}$ Lahore Medical College. Using RaoSoft, the sample size has been calculated to be 533 with a $5 \%$ error margin and a $92 \%$ confidence level. Hence, 533 online survey responses and used for data analysis.

Inclusion Criteria: All first to final year medical students and postgraduate students will be eligible for this study.

Exclusion Criteria: Medical students not willing to participate in study.
Study Procedures: Participants answered the questionnaire anonymously through "Google Forms" for a time span of five year students and also postgraduate students. In addition students provided general information about their year of study, age, gender, and the teaching method used in their school/college (i.e.: integrated or traditional teaching method). 533 response forms for data analysis done using SPSS version 23.

\section{RESULTS}

The study was carried out on medical students from all over Pakistan, with a calculated sample size of 535 individuals, according to the WHO formula. Out of 535 participants taking part in this research, 179(33.5\%) were from $1^{\text {st }}$ year MBBS, 94(17.6\%) from $2^{\text {nd }}$ year MBBS, $72(13.5 \%)$ from $3^{\text {rd }}$ year MBBS, $85(15.9 \%)$ from $4^{\text {th }}$ year MBBS, 55(10.3\%) from Final year MBBS and 50(9.3\%) were from postgraduate level.

\section{YEAR OF STUDY}

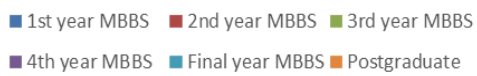

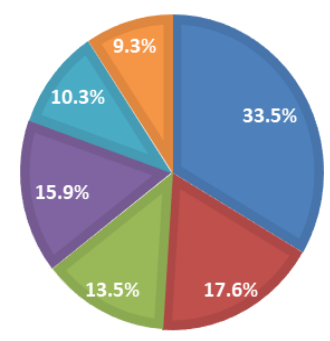

When asked to rate their course, majority of participants i.e. $213(39.8 \%)$ were satisfied with it, 153(28.6\%) and $113(21.2 \%)$ found it to be very good and excellent respectively while $31(5.8 \%)$ were not satisfied and $25(4.7 \%)$ thought it was bad.

\section{How do you rate your course?}

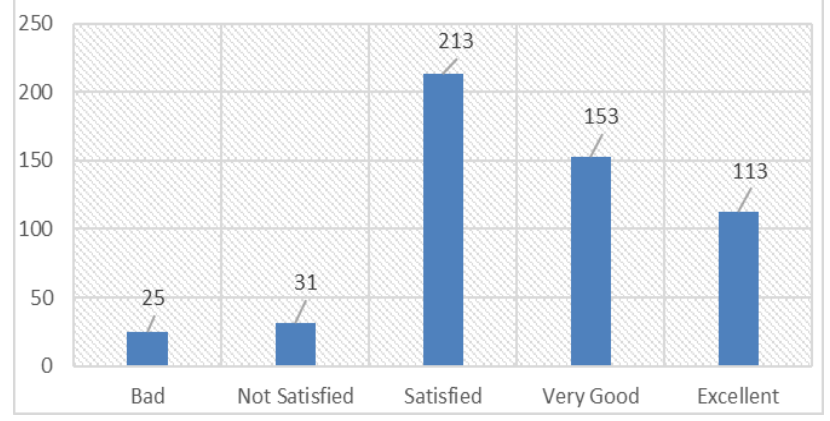

It was noteworthy to find out that majority of students, $246(46 \%)$ claimed Anatomy to be the most interesting subject in $1^{\text {st }}$ year MBBS which was closely followed by Physiology that 224(41.9\%) participants selected. Biochemistry was chosen as the most interesting subject by only $65(12.1 \%)$ students. 


\section{WHICH IS MOST INTERESTING SUBJECT IN FIRST YEAR MBBS?}

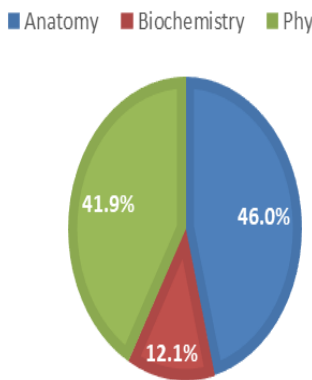

As for the preferable teaching method for better understanding of a topic, most students i.e. 234(43.7\%) selected the more traditional face-to-face interactive lectures, followed by small group discussions by $23.6 \%$ participants, tutorials by $10.8 \%$ and practical by $8.4 \%$. Meanwhile, assignments (1.7\%), viva (2.8\%), written assessments (3.7\%) and online lectures $(5.2 \%)$ were among least preferred teaching methods. 202(37.8\%) students were of opinion that mixed-type of lectures with a blend of multiple teaching techniques and tools like interactive, whiteboard, PowerPoint, illustrated etc. should be given. Whereas, $31.6 \%$ wanted only interactive, $17.8 \%$ opted for only illustrated and $6.7 \%$ and $6.2 \%$ selected only PowerPoint and whiteboard lectures respectively.

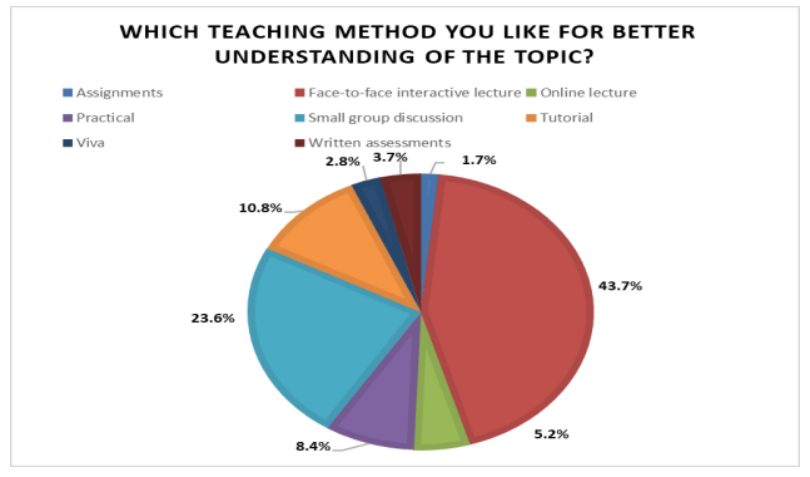

What is your preferred material to prepare physiology from?

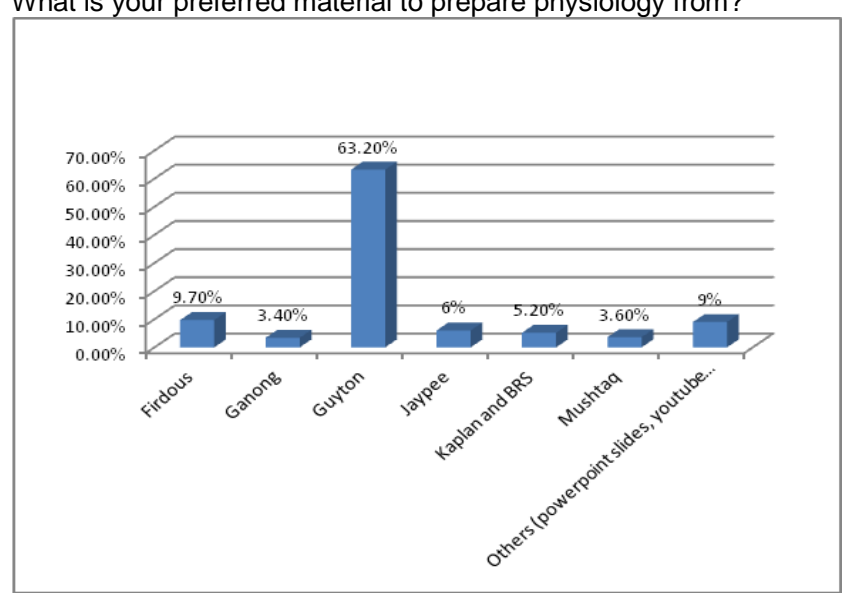

One of the most interesting question in our research was regarding the preferred study material used by the students to study Physiology. Majority of students, $63.2 \%$, prepared Physiology from Guyton and Hall Textbook of Medical Physiology which is indeed the golden standard textbook for this subject. It is significant to note that $9.7 \%$ students preferred Firdaus Review of Physiology which is a locally published short book. Similarly, 9\% participants turned to other sources like PowerPoint slides and YouTube medical channels which again are not a standard or authentic source of Physiology. Other less popular go to study sources selected were Jaypee- Essentials of Medical Physiology (6\%), Kaplan and BRS Physiology (5.2\%), Essentials of Medical Physiology by Mushtaq Ahmad $(3.6 \%)$ and Ganong's Review of Medical Physiology (3.4\%).

\begin{tabular}{|l|c|c|}
\hline Questions & Yes & No \\
\hline Are you interested in Physiology? & $88.0 \%$ & $12.0 \%$ \\
\hline Revision is required at the end of the lecture. & $83.0 \%$ & $17.0 \%$ \\
\hline $\begin{array}{l}\text { Do you like the way your physiology practical } \\
\text { are conducted? }\end{array}$ & $63.0 \%$ & $37.0 \%$ \\
\hline $\begin{array}{l}\text { My teacher seems to know if something is } \\
\text { bothering me. }\end{array}$ & $47.1 \%$ & $52.9 \%$ \\
\hline $\begin{array}{l}\text { In this class, my teacher accepts nothing less } \\
\text { than our full effort. }\end{array}$ & $69.5 \%$ & $30.5 \%$ \\
\hline $\begin{array}{l}\text { My teacher asks questions to be sure we are } \\
\text { following when she/he is teaching. }\end{array}$ & $81.1 \%$ & $18.9 \%$ \\
\hline $\begin{array}{l}\text { My teacher wants me to explain my answers - } \\
\text { why I think what I think. }\end{array}$ & $73.5 \%$ & $26.5 \%$ \\
\hline Our class stays busy and does not waste time. & $57.9 \%$ & $42.1 \%$ \\
\hline $\begin{array}{l}\text { If I don't understand something, my teacher } \\
\text { explains it another way. }\end{array}$ & $77.4 \%$ & $22.6 \%$ \\
\hline $\begin{array}{l}\text { My teacher knows when the class understands, } \\
\text { and when we do not. }\end{array}$ & $65.6 \%$ & $34.4 \%$ \\
\hline I like the ways we learn in this class. & $65.2 \%$ & $34.8 \%$ \\
\hline $\begin{array}{l}\text { This class does not keep my attention -I get } \\
\text { bored. }\end{array}$ & $51.6 \%$ & $48.4 \%$ \\
\hline $\begin{array}{l}\text { My teachers makes lessons interesting and } \\
\text { innovative. }\end{array}$ & $63.6 \%$ & $36.4 \%$ \\
\hline $\begin{array}{l}\text { Students speak up and share their ideas about } \\
\text { class work. }\end{array}$ & $64.3 \%$ & $35.7 \%$ \\
\hline $\begin{array}{l}\text { My teacher takes the time to summarize what } \\
\text { we learn each day }\end{array}$ & $71.0 \%$ & $29.0 \%$ \\
\hline $\begin{array}{l}\text { The comments that I get on my work help me } \\
\text { understand how to improve }\end{array}$ & $77.0 \%$ & $23.0 \%$ \\
\hline
\end{tabular}

We asked students about topic in Physiology that they found the most interesting. According to the results, a majority of $25.5 \%$ students were most interested in Blood physiology which was followed by Cardiovascular physiology (19.9\%), Cell plus Nerve and Muscle physiology (15.6\%), Respiratory physiology (9.6\%), CNS and Special Senses physiology (7.7\%), Endocrinology and Reproductive physiology (7.3\%), Renal physiology (4.5\%), GIT physiology (3.9\%), Sports physiology $(3.9 \%)$ and Aviation and Deep-sea physiology (2.1\%).

The most important aspect of our research was to evaluate students' perception of learning and teaching methodologies used in physiology class. We asked 16 closed-ended questions assessing the general perception of students related to this topic. The result is summarized as follows: 


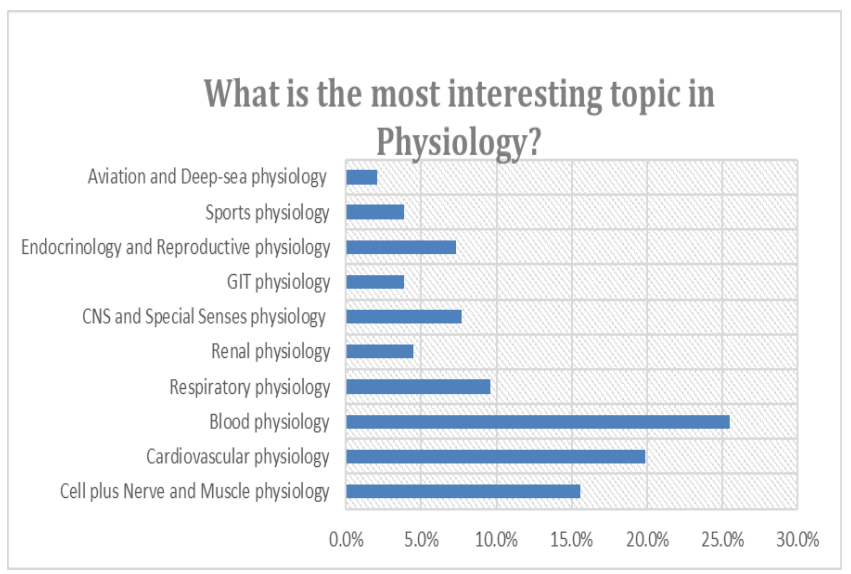

Would you like to opt physiology as your field of specialization in future?

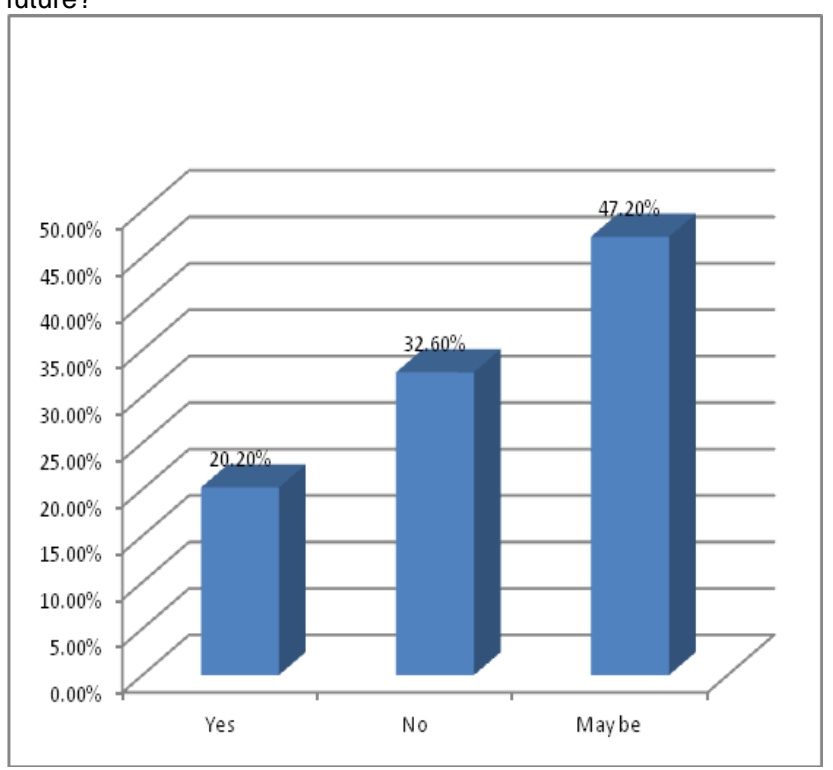

\section{DISCUSSION}

By far the greatest number of responses came from students of First Year MBBS at $179(33.5 \%)$. This could possibly be largely in part due to the study being aimed more directly towards first year subjects.

Anatomy was chosen as the most interesting subject by the majority of participants at $246(46 \%)$ with physiology being a close second at 224(41.9\%). A similar result was also observed in another study by Rajesh $\mathrm{K}$ Jha in Nepal in $2015^{14}$.

With regards to their preferred medium of teaching, a large majority opted for traditional face to face lectures $(43.7 \%)$ over online only lectures $(5.2 \%)$. The likely cause for the lack of popularity of online classes can be attributed greatly to lower peer interaction, less satisfactory rapport with instructors and lower self-perceived knowledge gains ${ }^{15}$.

In response to the usage of multimedia aids in lectures, the majority group $(37.8 \%)$ chose to select a "mixed" style, favoring the inclusion of PowerPoint slides, animations and other visual aids. This finding also corresponds well with a study done by Christian Herbert in 2017 on the usage of blended learning tools ${ }^{16}$.

Preferred study material for most students was their college assigned textbook, "Guyton and Hall Textbook of Medical Physiology" (63.2\%). It is interesting to note however, that only $9 \%$ students claimed to rely on internet based mediums of learning such as YouTube channels. This offers some degree of contrast to previous studies where internet resources are utilized quite often as supplementary aids ${ }^{17}$. It is possible that this contrast is due to demographic differences in the studies or possibly due to the students simply listing only their primary study material and not supplementary ones.

When asked whether students would wish to pursue physiology as a career option in the future, the largest response stated it was unsure $(47.2 \%)$, with $32.6 \%$ responding in the negative and only $20.2 \%$ in the affirmative. A study in 2014 by Arun Kumar cites that a common reason for this is that most students tend to prefer the clinical subjects encountered in the later years as worthwhile career options over the basic sciences ${ }^{18}$.

With regards to the results shown for the close ended questions, most students displayed their general satisfaction over the instructors' ability to convey concepts in varying ways $(77.4 \%)$. Students also mostly gave a positive response when asked whether the comments they received on their work aided in their learning (77\%).

Significantly lower scores were found however, with questions pertaining to student teacher rapport, with $52.9 \%$ students claiming that their teacher would not notice if something was bothering them during the lecture. $42.1 \%$ of the responses stated that the class felt like a waste of time and $48.4 \%$ complained of boredom during the lectures. Past studies do suggest that a lack of faculty development programs, further caused by time limitations for most clinical practitioners may act as barriers between them as teachers and their students ${ }^{19} 20$.

These results could also stem from a general lack of innovative teaching techniques as suggested by $36.4 \%$ students replying in the negative when asked whether their teachers made the lecture interesting and innovative. A further $37 \%$ also stated that they did not like the way their practical demonstrations were carried out. The significance of practical demonstration cannot be overlooked as, according to a study carried out in Germany by A-S Biesalski in 2015, most students tend to rate their impact to be far higher than textbook based learning ${ }^{21}$.

\section{CONCLUSION}

Physiology, science of life, is a discipline of biology whose goal is to comprehend the mechanisms of living things, from the ionic and molecular basis of cell activity to the integrated behavior of the entire body and the impact of the external environment has been. The students overall considered their Physiology course satisfactory. Most of the participants were happy with the current teaching and learning methodologies being employed in their Physiology class but were open to their combination with multimedia aids and modern techniques. Barriers such as student teacher communication may also need to be addressed. This may allow teachers to engage their students better in 
the lecture and facilitate their understanding of the concepts to a greater degree.

\section{Conflict of interest: Nil}

\section{REFERENCES}

1. Granjeiro ÉM. based teaching-learning method: a strategy to motivate and engage students in human physiology classes. Adv Physiol Educ. 2019;43(4):553-6.

2. Hwang I, Tam M, Lam SL, Lam P. Review of Use of Animation as a Supplementary Learning Material of Physiology Content in Four Academic Years. Electron $\mathrm{J}$ eLearning. 2012;10(4):368-77.

3. Rezende-Filho FM, da Fonseca LJS, Nunes-Souza V, da Silva Guedes G, Rabelo LA. A student-centered approach for developing active learning: the construction of physical models as a teaching tool in medical physiology. BMC Med Educ. 2014;14(1):1-9.

4. Behmer PM. Moving to learn: A meditative yoga approach to teaching and learning anatomy and physiology in multiple contexts. New Dir Adult Contin Educ. 2019;2019(161):67-77.

5. Bada SO, Olusegun S. Constructivism learning theory: A paradigm for teaching and learning. J Res Method Educ. 2015;5(6):66-70.

6. Eagleton S. An exploration of the factors that contribute to learning satisfaction of first-year anatomy and physiology students. Adv Physiol Educ. 2015;39(3):158-66.

7. Tempski P, Martins MA, Paro HBMS. Teaching and learning resilience: a new agenda in? medical education. Med Educ. 2012;46(4):345.

8. Dohn NB, Fago A, Overgaard J, Madsen PT, Malte $H$. Students' motivation toward laboratory work in physiology teaching. Adv Physiol Educ. 2016;40(3):313-8.

9. Lewis DI. The pedagogical benefits and pitfalls of virtual tools for teaching and learning laboratory practices in the biological sciences. High Educ Acad STEM. 2014;

10. Hassall C, Lewis DI. Institutional and technological barriers to the use of open educational resources (OERs) in physiology and medical education. Adv Physiol Educ. 2017;41(1):77-81.

11. Gopalan C, Klann MC. The effect of flipped teaching combined with modified team-based learning on student performance in physiology. Adv Physiol Educ. 2017;41(3):363-7.

12. Leuciuc F. Perception on physical education among students. Rev Românească pentru Educ Multidimens. 2018;10(2):134-43.

13. Lemos AR, Sandars JE, Alves P, Costa MJ. The evaluation of student-centredness of teaching and learning: a new mixedmethods approach. Int J Med Educ. 2014;5:157

14. Rajesh K Jha, Keshab R Paudel, Dev K Shah, Ajit K Sah, Sangharshila Basnet, Phoolgen Sah, and Sandeep Adhikari. Subject preferences of first- and second-year medical students for their future specialization at Chitwan Medical College and Teaching Hospital, Chitwan, Nepal - a questionnaire-based study. 2015

15. LaDonna S Hale, Emily A Mirakian, David B Day. Online vs classroom instruction: student satisfaction and learning outcomes in an undergraduate Allied Health pharmacology course. 2009

16. Cristan Herbert, Gary M Velan, Wendy M Pryor, Rakesh K Kumar. A model for the use of blended learning in large group teaching sessions. 2017

17. Salvatore Guarino, Eleonora Leopardi, Salvatore Sorrenti, Enrico De Antoni, Antonio Catania, Swethan Alagaratnam. Internet-based versus traditional teaching and learning methods. 2014

18. Arun Kumar, Kasturi Mitra, Sangeetha Nagarajan, and Bibek Poudel. Factors Influencing Medical Students' Choice of Future Specialization in Medical Sciences: A Cross-Sectional Questionnaire Survey from Medical Schools in China, Malaysia and Regions of South Asian Association for Regional Cooperation. 2014

19. Debra A DaRosa, Kelley Skeff, Joan A Friedland, Michael Coburn, Susan Cox, Susan Pollart, Mark O'connell, Sandy Smith. Barriers to effective teaching. 2011

20. S Schiekirka-Schwake, S Anders, N von Steinbüchel, J C Becker, T Raupach. Facilitators of high-quality teaching in medical school: findings from a nation-wide survey among clinical teachers. 2017

21. A-S Biesalski, M Zupanic, S Isenmann. [Nationwide evaluation of German university teaching methods in neurology]. 2015. 